\title{
Perceptions and Behavior of Investors Towards Stock Indices Performances in UAE
}

\author{
S. Edmund Christopher
}

\begin{abstract}
Investors' behavior and perception towards stock indices performances of the stock market was taken into account for this study. Relevant data was collected from 416 equity investors indulged in the stock market situated in diverse parts of UAE. This research focuses on how the investors' perceptions regarding stock indices movements of stock markets are affected by their irrational behavior, rational behavior and decision making behavior. In this study SEM approach was applied to analyze the data. The observations from the study disclosed that, the hypothesized model has a good fit and indicates that the anticipated model has the adequate fit, by way of satiating the suggested values. The finding indicates that investors are partly rational and partly irrational because they collect complete financial information and use this information for investment decision making and also use short cuts for decision making.
\end{abstract}

Key words--- Investors' Behavior, Investors' Perception, Structural Equation Modeling.

\section{INTRODUCTION}

A ventures investment decision making is based on risk sensitivity of distinct stakeholders. It covers subjective and objective risk norms. Financing in equity shares gives a chance to become a part of the possession of the business and also gives regular revenues as dividend income and capital appreciation. Rendering to customary investment theory, stakeholders are anticipated to gather ample and flawless data and use all accessible evidence to take balanced assessments in the stock market, for which the significance would boost the equity share price to be precise and mirror the fundamental value and it is intend to move up or down only if unanticipated thing happen. However, Behavioral finance theories adopt that distinct investors are not constantly composed and do not include industry, vital and technical investigation in investment judgments.

It emphases on how depositors essentially collect and comprehend information in order to make verdicts created on evidence and explores the impact of intellectual and emotions on speculation conclusions. Behavioral finance theory followers argue that depositors essentially behave absurdly while making speculative conclusions. Resolution creation method is created on heuristics such as bullishness, representativeness prejudice, attaching, Gamblers' misconception bias, expertise bias, prospects such as risk aversion, loss aversion and mental accounting and herding behavior. Individual investors usually buy stocks when prices are upward trend and sell the stocks when prices are in down ward trend.

International and domestic instability, war crimes, fraud and domestic or political unrest terrorist attack, scandals, and high oil price affect the stock market negatively. These factors including increase in inflation rate, increase in interest rates decrease or erode consumers spending capacity which may lead to lower business profits. Due to low profits, the company stock will be devalued. The investors become under confidence about the market. Individual investors are not willing to assume risk and they tend to sell the stock. Although several studies made huge contributions to the knowledge of how investors should behave in the stock market and how the investors actually behave in the stock market and its effect in the decision making procedure, they lack overall picture of relationships between the behavioral and traditional finance aspects and the investors' views about the stock market indices performances and how the stock indices performances are affected when rational and irrational groups of investors behave in different fashion.

This research focuses on how the investors' perceptions regarding stock indices movements of stock markets are affected by their irrational behavior, rational behavior and decision making behavior.

\section{Objectives of the study}

The following are the prime objectives of the research:

1. To examine the criteria's satisfying the given value, specifying a good fit between the hypothesized model

2. To study the relationship between the investor' behavior and their perceptions towards stock indices performances.

\section{Hypothesis of the research}

Based on the reviews of literature and the researcher's experience, the following hypotheses were framed:

$\mathrm{H}_{0}$ : Investors' irrational behaviors influence stock decision making process.

$\mathrm{H}_{0}$ : Investors' rational behaviors influence stock decision making process.

\section{Methodology of the research}

\section{A. Design and Type of the Research}

This examination pursues a distinct research plan. This examination is a causal-logical methodology, clarifying the impact of measurements of speculators' conduct on the stock records exhibitions by utilizing essential information. Essential information for investigation was gathered by study from individual value financial specialists with their sentiments, and encounters in settling on venture basic leadership procedure and recognitions about stock records exhibitions.

Financial specialists' perspectives and observations were estimated with self-directed survey. 
Five point scale with the score 5 showing emphatically concur and the score 1 demonstrating unequivocally differ was utilized to quantify financial specialists silly conduct, stock basic leadership procedure, and observations towards stock files exhibitions.

The same five point scale indicating 1 least influence and 5 most significantly influence was used to measure investors rational behavior. The primary data and secondary data were used for the study. The unit of analysis is the individual stock investors who invested in the stock market.

B. The populace comprises of individual financial specialists who put resources into the UAE Stock market. In light of pilot examine, test estimate is resolved.

Test estimate $\mathrm{n}=(\mathrm{ZS} / \mathrm{E}) 2$

Where,

$\mathrm{Z}=$ the institutionalized esteem that relates to the certainty dimension of $95 \%=1.96$.

$\mathrm{S}=$ Sample SD from Pilot investigation of 50 Sample = 0.52

$\mathrm{E}=$ Acceptable Error $=5 \%=0.05$.

Therefore the Sample measure $=(1.96 * 0.52 / 0.05) 2$

$=415.51$

$=416$

Out of the 500 questionnaires distributed, only 425 fully completed questionnaires were collected which amounted to $85 \%$ of the response rate. Out of 425 fully completed questionnaires 416 questionnaires were used for analysis. Convenience sampling technique was used to collect the samples.

Technique of Analysis

The accessible information were inspected and analyzed with the Structural Equation Model (SEM) with the AMOS program to test speculations 1 through 6 of this strategy is fitting when used to portray the connection between financial exchange records and measurements of speculators conduct through the Structural condition show investigation of way.

\section{A. Test of Reliability}

Cronbach alpha dependability test was utilized to analyse the unwavering quality of the instrument utilized for essential information gathering. Cronbach alpha estimates the unwavering quality of the divergent classes and comprises of appraisals for how much variety in scores of various factors is because of shot.

A coefficient is more prominent than or equivalent to 0.60 acknowledged and a decent sign of build unwavering quality. The example measure picked for the unwavering quality test was 50 . It has the estimation of 0.60 or more. The general hugeness dimension of Cronbach's alpha turned out to be 0.884 .

In this manner unwavering quality is $88.4 \%$ and the instrument was dependable to be utilized further in the examination. It infers the examination factors were solid (Hair et al 2010). The Results of testing dependability of the investigation factors are appeared table 1

\section{DATA ANALYSIS, RESULTS AND DISCUSSION}

Table 1: Results of Reliability Analysis For Dimensions Of Behavior And Perceptions Of Investors.

\begin{tabular}{|l|l|l|}
\hline Dimensions & $\begin{array}{l}\text { No of } \\
\text { attributes }\end{array}$ & $\begin{array}{l}\text { Cronbach's } \\
\text { Alpha }\end{array}$ \\
\hline Individual investors profile & 7 & 0.637 \\
\hline $\begin{array}{l}\text { Irrational behavioral factors } \\
\text { influencing investment decisions }\end{array}$ & 22 & 0.754 \\
\hline $\begin{array}{l}\text { Rational factors influencing } \\
\text { investment decisions }\end{array}$ & 40 & 0.901 \\
\hline $\begin{array}{l}\text { Individual Equity investors' decision } \\
\text { making process }\end{array}$ & 4 & 0.600 \\
\hline $\begin{array}{l}\text { Perceptions of determinants of stock } \\
\text { indices performance }\end{array}$ & 9 & 0.690 \\
\hline $\begin{array}{l}\text { Overall reliability analysis for factor } \\
\text { influencing Individual Equity } \\
\text { investors behavior and Stock indices } \\
\text { performances }\end{array}$ & 59 & 0.884 \\
\hline
\end{tabular}

\section{B. Structural equation modeling approach (SEM)}

SEM is a factual displaying method that consolidates a few measurable strategies to create a lot of connections between at least one clear free factors are accessible, so does it might be either proceeds or discrete in structure and at least one ward factors that could be inspected (Hair et al., 2006).

It is seen that the main role of utilizing the SEM is to clarify the example of entomb related reliance relationship simultaneously that are observed to be between a lot of inert factors which can estimate by at least one watched factors.

So as to perceive the conjectured model for the given example information, the quantity of Goodness of Fit (GOF) lists, for example, the Goodness-of-fit record (GFI), the Adjusted Goodness-of-fit list (AGFI), the Comparative Fit Index (CFI), the Nor drug Fit Index (NFI), the Root Mean Square Residuals (RMR), and the Root Mean Square Error of Approximation (RMSEA), The fundamental target of supreme fit lists is to decide how well a foreseen model fit the example information (McDonald and Ho, 2002).

\section{Goodness-of-fit assessment}

SEM was utilized to examine the bent of the model focused upon the got tests.

As recommended by Anderson and Gerbing (1988), estimation model to test the reliability and levelheadedness of the overview instrument was broke down first and by utilizing AMOS-V18 the basic model has been analyzed. For the assurance of testing the model fit invalid speculation and elective theory are planned.

\section{Model fit Hypothesis}

Null hypothesis $\left(\mathrm{H}_{0}\right)$ : There is good fit among hypothesized model and the collected figures.

Alternate hypothesis $\left(\mathrm{H}_{1}\right)$ : There is no good fit among hypothesized model and the collected statistics.

Table 2 shows the approximations of the model fit indices from AMOS structural modeling. 
Table 2: Goodness-Of-Fit Index Of Sem

\begin{tabular}{|l|l|l|l|}
\hline Criteria & $\begin{array}{l}\text { Calculation } \\
\text { Results }\end{array}$ & $\begin{array}{l}\text { Suggested } \\
\text { Value }\end{array}$ & Description \\
\hline $\begin{array}{l}\text { Chi-Square }\left(^{2}\right) \\
\text { Value (DF 31) }\end{array}$ & 42.179 & & \\
\hline $\begin{array}{l}\text { Chi- } \\
\text { square/degrees of } \\
\text { freedom }\end{array}$ & 1.361 & $\begin{array}{l}\leq 5.00 \text { ( Hair et } \\
\text { al., 1998 ) }\end{array}$ & Good \\
\hline P. value & 0.087 & $\begin{array}{l}>0.05 \text { ( Hair et } \\
\text { al., 1998) }\end{array}$ & Good \\
\hline GFI & 0.939 & $\begin{array}{l}>0.90 \text { (Hair et } \\
\text { al. 2006 ) }\end{array}$ & Good \\
\hline AGFI & 0.902 & $\begin{array}{l}>0.90 \text { (Daire et } \\
\text { al., 2008) }\end{array}$ & Good \\
\hline CFI & 0.974 & $\begin{array}{l}>0.90(\text { Hu and } \\
\text { Bentler,1999) }\end{array}$ & Good \\
\hline NFI & 0.976 & $\begin{array}{l}>0.90 \text { (Gerbing } \\
\text { et al, 1992) }\end{array}$ & Good \\
\hline RMR & 0.077 & $\begin{array}{l}<0.08(\text { Hair et } \\
\text { al. 2006) }\end{array}$ & Good \\
\hline RMSEA & 0.036 & $\begin{array}{l}<0.08(\text { Hair et } \\
\text { al. 2006) }\end{array}$ & Good \\
\hline
\end{tabular}

Since the criteria fit are satisfying all the suggested values, Null hypothesis is accepted. It indicates that this proposed model is suitable for further analysis.

\section{E. SEM Assessment}

In the Structural model, the connection between the exogenous and endogenous factors is displayed by utilizing a single direction impact relationship. By applying AMOS $\mathrm{V} 18$ all parameters were evaluated once more. Those parameters included way co productive among exogenous and endogenous factors, changes of the dormant factors, stacking co effective, mistake fluctuations/co differences for the deliberate factors as appeared in Figure 1.

The Observed variables used in the structural equation model are endogenous variables, Heuristic, Prospect, Herding, Personal and Financial needs, Firm Image, Accounting and Financial Information, Neutral Information, Advocate Recommendation, Decision making process and Stock Indices Performance

Unobserved, exogenous variables are Investors' Irrational behavior, Investors' Rational behavior, e1: Error term for Heuristic, e2: error term for Prospect, e3: error term for Herding, e4: error term for Personal and Financial needs, e5: error term for Firm Image, e6: error term for Accounting and Financial Information, e7: error term for Neutral Information, e8: error term for Advocate Recommendation, e9: error term for Decision making process, e10: error term for Stock Indices Performance.

Hence numbers of variable in the SEM are

Number of variables in this model 22

Number of observed variables $\quad 10$

Number of unobserved variables 12

Number of exogenous variables 12

Number of endogenous variables $\quad 10$

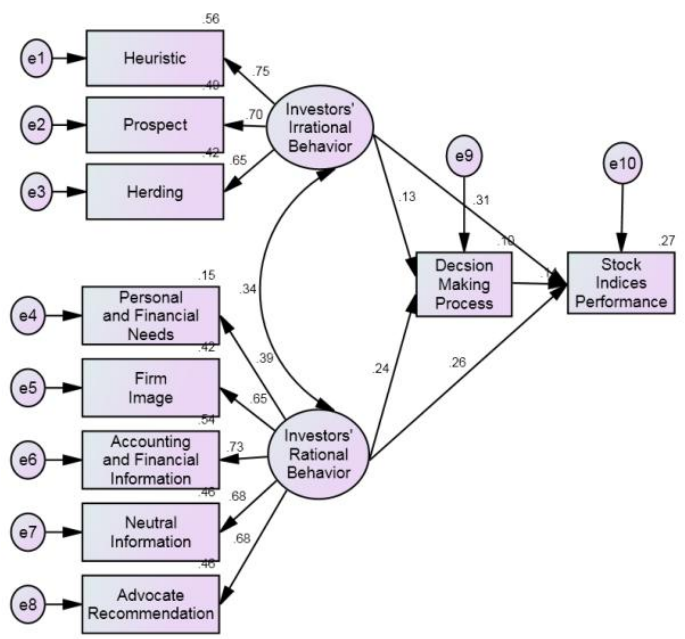

Fig. 1: SEM on Stock indices performance

Operational Definitions and Measurement of the Variables

\section{F. Irrational behavior}

Irrational investors are the people who are trying to make good investment decisions but make predictable mistakes in investment decision making. Irrational investor behavior is defined as using shortcuts for collection and analysis of information before buying and selling of equity shares without doing fundamental analysis. This is measured by Researchers as developed from (Le PhuocLuong et al, 2011) Investors' irrational behavior is determined by three latent variables and 17 statements of 9 measured variables as follows.

1. Heuristic consists of five indicators, i.e. over confidence, Representativeness, Anchoring, Gamblers' fallacy, Familiarity bias.

2. Prospect consist of three indicators, i.e. Risk aversion, Loss aversion, Mental accounting.

3. Herd behavior consist of other investors' decision of purchasing and selling, other investors' decision of the stock volume, other investors' decision on the type of stock, following reactions of changes of other investors' decision.

\section{G. Rational behavior}

Rational investor behavior is defined as considering and analyzing all available economic, industry and company information before choosing the best alternatives from various investment alternatives available in the stock market and always seeking to maximize the expected utility. This is measured by Researchers as developed from Investors' rational behavior is determined by five latent variables and 31 measured variables as follows.

1. Personal and Financial needs consists of 8 variables

2. Firm- Images consists of 8 variables

3. Accounting and Financial information consists of 7 variables

4. Neutral information consist of 4 variables

5. Advocate Recommendation consists of 4 variables. 


\section{H. Decision Making Process}

It involves what they need or want, their awareness of various investment alternatives, their information- gathering activities, their evaluation of alternatives and their selection of best alternatives from various alternatives available to them. The measurement of decision making process from Salman A.Q et.al, (2012) was done using Likert scale. The scale ranges from 5 , that indicates strongly agree and 1 that indicates strongly disagree.

\section{Stock indices Performances}

The general movement of the market is typically measured by stock indices representing the entire market. The most popular benchmark indices are S\&P CNX Nifty Index and BSE- SENSEX. The instrument of perceptions towards stock indices performances was done using a Likert scale that measures the factors influencing stock indices performances in which that in score 5 indicates strongly agree and score 1 shows strongly disagree.

\section{J. Hypothesis Testing}

The SEM Analysis shows that the test of hypotheses from $\mathrm{H} 1$ to $\mathrm{H} 5$. All the hypotheses are accepted because $\mathrm{H} 2, \mathrm{H} 3$, $\mathrm{H} 4$ and $\mathrm{H} 5$ are significant at $1 \%$ level and $\mathrm{H} 1$ is significant at 5\% level. All these evidences are presented in Table 3.

Here the coefficient of financial specialists' unreasonable conduct on basic leadership process is 0.150 that signifies the fractional impact of speculators' nonsensical conduct on basic leadership process, holding extra factors as consistent. The normal positive sign signifies that such impact is certain that basic leadership procedure would flood by 0.150 for each unit heightening in speculators' unreasonable conduct and this coefficient esteem is pivotal at 5\% level. The coefficient of speculators' balanced conduct on basic leadership process is 0.301 speaks to the incomplete impact of financial specialists' sane conduct on basic leadership process, holding the extra factors as steady. The assessed positive sign suggests that such impact is certain that basic leadership procedure would increment by 0.301 for each unit increment in financial specialists' levelheaded conduct and this coefficient esteem is huge at $1 \%$ level.

Table 3: Variables and Estimation of Structural Equation Model

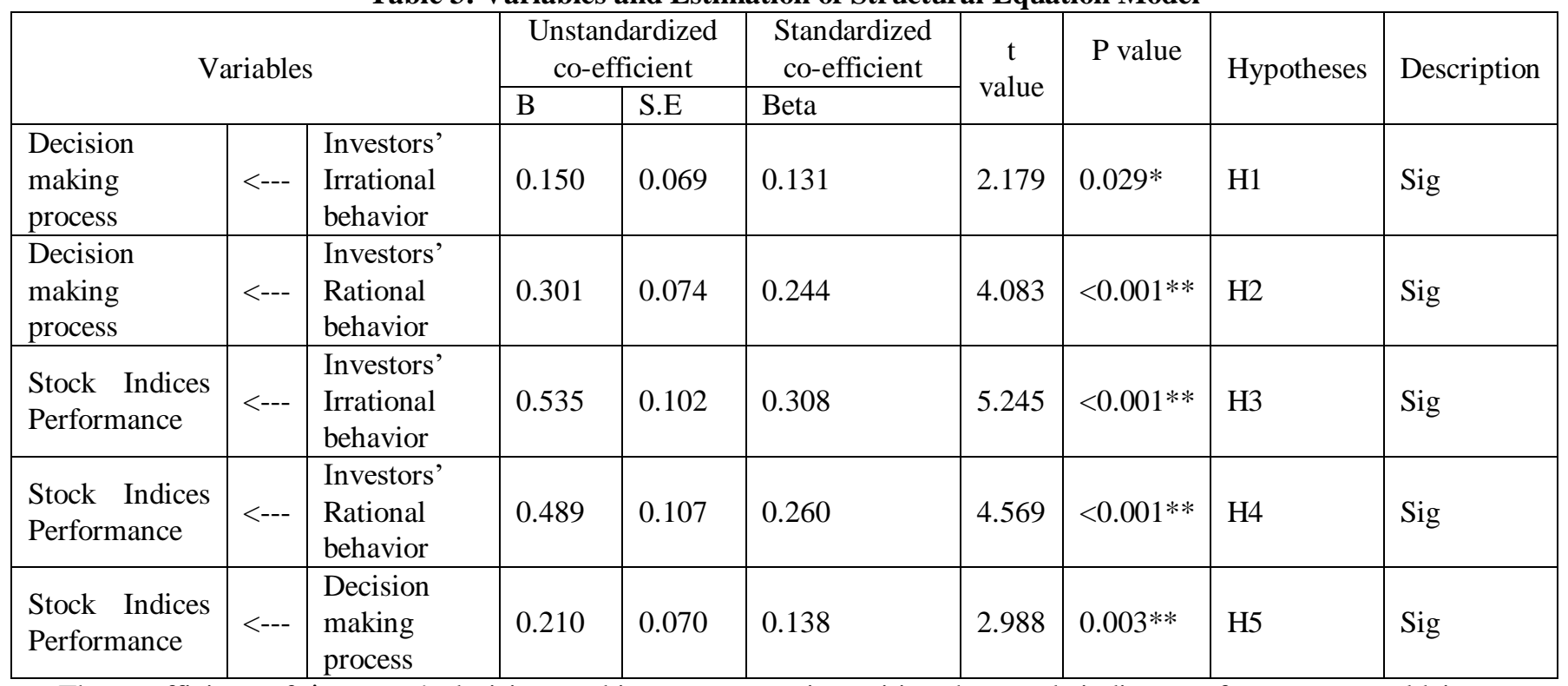

The coefficient of investors' decision making process behavior on stock indices performances is 0.210 represents the partial effect of investors' decision making process behavior on stock indices performances holding the other variables as constant. The estimated positive sign implies that such effect is positive that stock indices performances would increase by 0.210 for every unit increase in investors' decision making process behavior and this coefficient value is significant at $1 \%$ level. The coefficient of irrational behavior on stock indices performance is 0.535 represents the partial effect of effect irrational behavior on stock indices performances, holding the other variables as constant. The estimated positive sign implies that such effect is positive that stock indices performances would increase by 0.535 for every unit increase in rational behavior and this coefficient value is significant at $1 \%$ level. The coefficient of rational behavior on stock indices performances is 0.489 represents the partial effect of rational behavior on stock indices performances holding the other variables as constant. The estimated positive sign implies that such effect is positive that stock indices performances would increase by 0.489 for every unit increase in rational behavior and this coefficient value is significant at $1 \%$ level.

\section{DISCUSSION}

The findings of the researchare discussed below:

It concerns the influence of investors' irrational behavior on the decision making process. It indicates that the investors' irrational behavior positively influence the decision making behavior. It suggests that irrational behavioral factors can make the investors to change their belief or intention to buy, held for sale or sale the securities. The belief was based on the economical, financial and other information about the intrinsic value of share available in the stock market. 

irrational investor do not read, examine, analyze and interpret information but they use short ways for making investment. These results of irrational behavior provide changes in the decision making process. From this evidence, Hypothesis 1 is strongly accepted.

It concerns the influence of investors' rational behavior on the decision making process. It indicates that the investors' rational behavior also positively influence the decision making process. It suggests that rational behavioral factors also can make the investors to change their belief or intension to buy, held for sale or sale of equity shares. The rational investor collects and analyzes the financial statements of the companies to take stock investment decisions in the stock market. Analyzing the financial and non financial information motivates the investor to change the investment decision. This rational behavior determines decision making behavior of investors to interpret and analyze the information. Therefore, as per the traditional finance, rational investor should critically analyze the financial and nonfinancial information to take investment decision based on intrinsic value of share. From this evidence, Hypothesis 2 is strongly accepted.

It also concerns the effect of Irrational behavior on perceptions towards stock indices performances. Test results indicate that irrational behavior positively affects the stock indices performances. It means that the irrational behavior has a significant effect on the performances of the Bench mark stock indices.

Dispositions towards stock files exhibitions can be certain on the grounds that it is shaped from the experience and information of the financial specialist just as the encounters of other people who can alter course because of impact of individuals, for example, companions, eyewitnesses and controllers. In the event that the conduct of the speculators towards stock records exhibitions is sure, while different financial specialists or their companions don't bolster his observation, at that point the speculators' recognition towards stock lists can change conflicting.

Therefore investors' irrational behavior affects stock indices performances. With this evidence, hypothesis 3 of the study was admitted and so irrational behavioral factors are really effective on performances of the Bench mark stock indices in Indian stock market.

The trial of Hypothesis 4 is identified with the impacts of speculators' sane conduct on recognitions about stock records exhibitions. It demonstrates that sound speculator conduct emphatically influences the stock lists exhibitions. Financial specialists' conviction depends on data accessible in the securities exchange. After the distribution of data just as fiscal reports and money related execution data contained in the budget summaries, speculators will turn out to be increasingly educated with budgetary exhibitions figures. Diverse financial specialists are getting distinctive data and their capacity to translate the data is likewise extraordinary. This conduct additionally can change the recognitions about stock lists exhibitions. With this proof, Hypothesis 4 is affirmed.

The test of Hypothesis 5 is dealt with the effect of decision making process on stock indices performances. The test result shows that Stock decision making process
At the time of publication of these information, the

positively affect the performances of the stock indices performances. It means that investors' decision making behavior can change the perceptions about stock indices performances. An individual investor's investment decisions would basically be in the form of two types of reasoning namely traditional finance and behavioral finance. These types of reasoning will be related to risk perception of individuals. Traditional finance would cover the objective risk criteria and Behavioral finance cover subjective risk criteria. These two criteria can change the perceptions about the stock indices performances. With this evidence, Hypothesis 5 is accepted.

\section{CONCLUSION}

The main purpose of the research was to observe how the various dimensions of investors' behavior such as investors' rational behavior, irrational behavior and their stock decision making behavior affect perceptions towards bench mark stock indices performances, i.e. BSE-SENSEX and NSE-Nifty. The results of the study proved that investors' behavior have positive effects on stock indices performances. Furthermore it is also proved that there is a strong positive relationship between investor behavior and perceptions towards stock indices performances. The finding indicates that investors are partly rational and partly irrational because they collect complete financial information and use this information for investment decision making and also use short cuts for decision making.

It is suggested here that once investors' behavior improved, the stock indices performances will also go high. The stock brokers, Professionals, asset managers and investors can apply the results of this paper for selecting proper investment strategies making safety and optimal return investments in the stock market. Therefore investors' behavior should be improved by controlling emotions and psychological biases.

\section{REFERENCES}

1. Anderson, J. C., \&Gerbing, D. W. (1988). Auxiliary condition displaying by and by: A survey and suggested two-advance methodology. Mental release, 103(3), 411.

2. Bentler, P. M., \&Bonett, D. G. (1980).Significance tests and decency of fit in the investigation of covariance structures. Psychological notice, 88(3), 588.

3. McDonald, R. P., and Ho, M. H. R. (2002). Standards and practice in detailing auxiliary condition examinations. Mental strategies, 7(1), 64 .

4. PhuocLuong, L., \&Thi Thu Ha, D. (2011). Conduct factors impacting singular speculators' basic leadership and execution.: An overview at the Ho Chi Minh Stock Exchange.

5. Badri, A.(2009). Learning of Behavioral Finance and Asset Management. Tehran: Kayhan Publishing Company. 50-69.

6. Bidgoli, G h., Shahiari, S. (2007). A review and social mass testing of financial specialists utilizing deviations of stock comes back from market yields at the Tehran Stock Exchange from 2001 to 2005. Bookkeeping and Audit Reviews, 49, 25-44. 
7. Campbell TC, Gillaspy JA, Thompson B (1995) A corroborative Factor investigation Paper introduced at the yearly gathering of the South West Educational association, Dellas-6.

8. Chen, A.H.L., Cheng, K. what's more, Lee, Z.H. (2011).The conduct of Taiwanese financial specialists in Asset allocation. Asia Pacific Journal of Business Administration, Vol.3 No 1. pp 62-74

9. Cohen,J 1988, Statistical power investigation for the conduct science 2 nd release, L Erlbaum Associates, Hillsdale, N. J.

10. Daire .H., Joseph C Michael RM (2008) Structural Equation Modeling Guidelines for Determining Model fit Electron.J Bus. Res. Techniques 6(1): 53-60

11. Hair JF, Anderson RE Tantham RL, Black WC (1998), Multivariate information investigation, Prentice-Hall, Upper Saddle River, New Jersey in.

12. Hair JF, Anderson RE Tantham RL,(2006), Multivariate information analysis, 10th release Prentice-Hall, New Jersey in. Malek AL-Majali, NikKamariahNik Mat (2011) Modeling the forerunners of web banking administration selection in Jordan; A Structural Equation Modeling approach Journal of Internet Banking and Commerce.16 (1) 8-13.

13. Hair JF, Anderson RE Tantham RL, Black WC, Babin BJ (2006), Multivariate information analysis,6th release Pearson Education, New Delhi 734-735.

14. Hair JF, Black WC, Babin BJ, Anderson RE (2010), Multivariate information analysis,6th release Pearson Education, New Delhi 734-735

15. Kaheman Daniel, Tversky Amos (1973). Prospect hypothesis; "An investigation of choices under hazard" Econometrica, No 47. 263-291

16. Kaheman Daniel, Tversky Amos (1974). Judgment under vulnerability: Heuristics and Biases, Science. New Series, 185(4157), 1124-1131

17. Lai, M.M.. Low K.L.T., Lai, M.L (2001) Are Malaysian financial specialists levelheaded?The Journal of Psychology and Financial markets, 2 (4), 210-215.

18. Muhammad,N.M.N., Abdullah.M (2009) Investment basic leadership style; Are Malaysian financial specialists levelheaded chiefs? Bury disciplinary Journal of Contemporary Research in Business, Vol 1 no 3 pages 96-108

19. Ross,S.A, Westerfield R.W, Jaffe.J. (2010) corporate money Ninth release (Page 43) McGraw Hill International Edition. ISBN 978-007-131308-7

20. Syed T.S., Parthasarathi.S (2012) An exact investigation of components impacting Indian individual Equity financial specialists' Decision making and conduct. European Journal of Business and Management ISSN 2222-1905 Vol 4 No 18.

21. Salman.A.Q.,Kashif.U.R., Ahmed.I.H (2012) Factors influencing speculation basic leadership of value support managers, Wulfenia Journal Klagenfurt Austria ISSN 1561-882X Vol 19 No10

22. Edmund Christopher, "Banking Inventiveness a Catalyst for Demonetization Disorder - A Study with Special reference to New Generation Banks", International Journal of Engineering and Technology, ISSN: $2227-$ 524X7(3,6)(2018)168-171,

23. Edmund Christopher and Srinivasan, (2018) "The Impact Of Adopting ERP On Key Performance Indicator By The Mediation Effect Of Critical Success Factors And Performance Indicators In Automobile Ancillary Industries" International Journal of Public Sector Performance Management (IJPSPM).

24. Kinslin and Pradeep "The executives Education in Kerala-Impact on Employability", International Journal of Engineering and Technology, ISSN: $2227-$
$524 X 7(3,6)(2018) 375-378$, www.sciencepibco.com/Index/php/IJET

25. Pradeep "Sex Factor-Impact on Employability: Special Reference to Management Students in Kerala", International Journal of Engineering and Technology, ISSN: $\quad 2227-524 X 7(3,6)(2018) 368-374$ www.sciencepibco.com/Index/php/IJET

26. Lakshmi Radhakrishnan, Panchali Das., 'Effect of moral learning condition in encouraging scholarly trustworthiness', Advance Research Journal of Multidisciplinary Discoveries, Vol.- 8.0,Issue - 1 , Chapter - VIII - Jan-2017, E-ISSN NO : 2456 - 1045

27. NithyaDaimy KM., Reengineering the Process of Performance Evaluation towards the Employee's Development - Need of the Time in IT Industry', Journal of Chemical and Pharmaceutical Sciences, ISSN: 0974 2115, JCPS Volume 9 Issue 4, October - December 2016.

28. NithyaDaimy KM., 'Rationale behind the pool of it experts centering Indian it industry - a scientific examination', Journal of Chemical and Pharmaceutical Sciences, ISSN: 0974-2115, JCPS Volume 9 Issue 4, October - December 2016.

29. Srinivaasan., 'Channel The Women Entrepreneurial Effort To Manage Global Crisis Is The Need Of An Hour - A Focus Based On Indian Context"', International Journal of Management Research - Singapore, Vol. 4, Issue 10, October 2016 IF-4.88 ISSN: (2321-1709)

30. K. Asha S. Edmund, An examination on Buying Behavior of Customers towards Branded and Nonmarked gold Jewelry with reference to kanyakumari district; International Journal of Management (IJM), ISSN 0976 - 6502(Print), ISSN 09766510.

31. Hu, L.T. what's more, Bentler, P.M. (1999) Cut - off criteria for Fit lists in Co change Structure examination: ordinary Criteria versus New options, Structural condition displaying, Vol. 6 no 1 p 1-55

32. Renganatha., R., Balachandra. S., and Govindarajan.K (2012) Costomer discernment towards banking part: Structural condition displaying approach. African Journal of Busines Management Vol 6 (46) pp 11426-11436 